\title{
ARCHEOLOGIA CHRZEŚCIJAŃSKA W KATOLICKIM UNIWERSYTECIE LUBELSKIM
}

Pani profesor Anna Sadurska powiedziała kiedyś: „w dziedzinie historii sztuki wczesnochrześcijańskiej Profesor Barbara Filarska jest w naszym kraju prawdziwym pionierem, tworząc dosłownie z niczego dwie kwitnące i tętniące życiem naukowym placówki w Lublinie i Warszawie". A zatem, pokazując w jaki sposób archeologia chrześcijańska, i ściśle $z$ nią powiązana historia sztuki wczesnochrześcijańskiej, weszły na stałe do programu nauczania w Katolickim Uniwersytecie Lubelskim, mówić trzeba przede wszystkim o dokonaniach Pani Profesor Filarskiej. Obecność tych dyscyplin w naszym Uniwersytecie, i to już od blisko 30 lat, jest bez wątpienia Jej zasługą.

Pierwszego czerwca 1969 roku powołano Barbarę Filarską na stanowisko docenta na Wydziale Nauk Humanistycznych Katolickiego Uniwersytetu Lubelskiego, powierzając Jej kierowanie Katedrą Historii Sztuki Starożytnej i Archeologii Klasycznej ${ }^{1}$. Przedmiotem zajęć miała być przede wszystkim sztuka starożytnej Grecji i Rzymu. W początku lat siedemdziesiątych nastąpił ważny zwrot w profilu badawczym Katedry - obok sztuki starożytnej przedmiotem pracy naukowej i dydaktycznej stała się też sztuka wczesnochrześcijańska. Impulsem dla podjęcia badań nad tą tematyką było założenie w KUL w 1969 r. przez o. Jana Szymusiaka SJ i prof. Leokadię Małunowiczównę Międzywydziałowego Zakładu Badań nad Antykiem Chrześcijańskim. Kierowana przez docent Filarską Katedra współpracowała od początku z Zakładem m.in. w organizowaniu sympozjów ${ }^{2}$, podczas których ,wiele miejsca poświęcano archeologii i ikonografii wczesnochrześcijańskiej”3. W spotkaniach tych brali udział m.in. R. Jacquard i V. Saxer, profesorowie Papieskiego Instytutu

${ }^{1}$ Por. AU KUL, Akta osobowe Barbary Filarskiej, A 744.

2 Odbyły się m.in. w dniach: 23-24 maja 1973 r. w Lublinie (Aktualne problemy architektury i ikonografii wczesnochrześcijańskiej); 31 maja - 2 czerwca 1976 r. w Krakowie (Świętość $i$ kult świętych w okresie patrystycznym); 16-19 października 1979 r. w Lublinie (Relacje między architekturq a liturgiq w IV $i \mathrm{~V}$ wieku).

3 A. Malinowski, 10-lecie Międzywydziałowego Zakładu Badań nad Antykiem Chrześcijańskim, RTK 26(1979) z. 4, s. 18; tamże s. 9-15 (wykaz tytułów prelekcji pierwszych 17 sympozjów). 
Archeologii Chrześcijańskiej (Pontificio Istituto di Archeologia Cristiana), z którym nawiązano wówczas stałą, trwającą do dziś współpracę ${ }^{4}$.

W piśmie do Rektora z dnia 12 III 1971 r., Pani docent Filarska zawiadamiała o swym zamiarze ,podjęcia na naszym uniwersytecie poważnie zakrojonych badań w dziedzinie archeologii chrześcijańskiej” i prosiła o zgodę na wyjazd do Rzymu ,w celu zapoznania się z autopsji z zabytkami antyku chrześcijańskiego" "5.

Zagadnienia, które stały się wówczas przedmiotem zainteresowań Pani Docent (tituli rzymskie, najstarsze katakumby, początki malarstwa katakumbowego, geneza bazyliki i związki kościoła z synagogą), pozwoliły Jej wkroczyć od razu na teren najistotniejszych problemów, z jakimi zmagano się w głównych ośrodkach badawczych archeologii chrześcijańskiej. Okazją do kontaktu z zagranicznymi środowiskami badaczy antyku chrześcijańskiego były m.in. wyjazdy na zagraniczne stypendia (do Rzymu, Leuven i Louvainla-Neuve) i międzynarodowe kongresy archeologii chrześcijańskiej, w których docent Filarska, a później i inni pracownicy Katedry starali się w miarę możliwości uczestniczyć.

Efektem prowadzonych przez Panią Docent badań, miały się stać nie tylko publikacje - przede wszystkim pionierskie na naszym rynku wydawniczym podręczniki $^{6}$, ale także zajęcia dydaktyczne, których celem było propagowanie archeologii chrześcijańskiej wśród studentów i kształcenie przyszłych badaczy.

Od roku akademickiego 1971/72 docent Filarska wykładała już archeologię chrześcijańską na Wydziale Teologii, a dla studentów historii sztuki prowadzić zaczęła wykłady monograficzne poświęcone sztuce późnego antyku i archeologii wczesnochrześcijańskiej (wśród omawianych tematów znalazły się m.in. ikonografia wczesnochrześcijańska, początki budownictwa kościelnego, kościoły Rzymu, wczesnochrześcijańska sztuka sepulkralna).

W tym samym czasie Pani Docent postanowiła również swoje seminarium ukierunkować na problematykę sztuki wczesnochrześcijańskiej. Od 1972 r.

${ }^{4}$ Formą tej współpracy były studia podejmowane w Instytucie przez pracowników Katedry, najpierw Elżbietę Jastrzębowską, później Bożenę Iwaszkiewicz-Wronikowską, która w 1985 r. uzyskała licencjat.

${ }^{5}$ Por. AU KUL, Akta osobowe Barbary Filarskiej, A 744.

${ }^{6}$ W dorobku naukowym Barbary Filarskiej znalazło się wiele publikacji z dziedziny archeologii chrześcijańskiej (ich wykaz zob. w dedykowanym jej 20-23 tomie „Vox Patrum” 1992, s. 1619 ), w tym m.in. pionierskie w naszym kraju opracowania o charakterze podręcznikowym: Początki architektury chrześcijańskiej (Lublin 1983) oraz Początki sztuki chrześcijańskiej (Lublin 1985), a ostatnio - Archeologia chrześcijańska (Warszawa 1999). Niebagatelne znaczenie mial również jej udział w przedsięwzięciach popularyzujących sztukę wczesnochrześcijańską, jak np. publikacja polskiego przekładu książki Marcela Simona Cywilizacja wczesnego chrześcijaństwa (Warszawa 1979), czy edycja III, poświęconego tej właśnie problematyce, tomu Sztuki świata (Warszawa 1993). 
powstawać zaczęły pod Jej kierunkiem prace magisterskie ${ }^{7}$, a w latach osiemdziesiątych również doktorskie ${ }^{8} \mathrm{z}$ dziedziny sztuki wczesnochrześcijańskiej.

Sztuka wczesnochrześcijańska stała się też przedmiotem zainteresowań pracujących w Katedrze młodszych pracowników naukowych. Mgr Anna Witzówna rozpoczęła badania nad wczesnochrześcijańską symboliką sepulkralną, a zatrudniona po jej odejściu na stanowisku asystenta mgr Elżbieta Jastrzębowska, jako temat pracy doktorskiej wybrała mitologię antyczną w ikonografii mozaik wczesnochrześcijańskich ${ }^{9} \mathrm{i}$ już $\mathrm{w}$ drugim roku swojej pracy oddała do druku pierwsze ze swych, licznych później, publikacji na temat sztuki wczesnochrześcijańskiej ${ }^{10}$. Kiedy E. Jastrzębowska zrezygnowała z pracy w KUL, decydując się na dalsze studia za granicą, Pani Profesor Filarska szukała jej następcy wśród szczupłego jeszcze wówczas w Polsce grona osób zajmujących się archeologią chrześcijańską. Wybór padł na niżej podpisaną. Byłam wówczas absolwentką archeologii śródziemnomorskiej Uniwersytetu Warszawskiego, a w ramach pracy magisterskiej opracowałam znaleziony podczas polskich wykopalisk w Sudanie kamienny fryz $\mathrm{z}$ wczesnochrześcijańskiej katedry w Faras ${ }^{11}$. Pracując od 1973 r. do dziś w Katedrze, na stanowiskach kolejno asystenta, adiunkta i wreszcie, od 1999 r., profesora, prowadzę badania nad początkami sztuki okresu wczesnego chrześcijaństwa publikując ich wyniki m.in. w książkach Picturae sacrae. Motywy ikonograficzne malowidet przedkonstantyńskich w chrześcijańskich katakumbach Rzymu (Lublin 1990) i Vestigia christianorum. Świadectwa obecności chrześcijan w Rzymie przedkonstantyńskim (Lublin 1994).

${ }^{7}$ Por. r. 1972: K. Wojnarska, Kościoty tytularne i bazyliki rzymskie III-IV wieku; 1973: J. Kołnierzak, Styl malarstwa chrześcijańskiego III wieku; 1977: E. Tatar-Próchniak, Sceny z dzieciństwa Chrystusa w ikonografii wczesnochrześcijańskiej; D. Próchniak, Poczq̨tki architektury chrześcijańskiej w Armenii. Eczmiadzyn i problem genezy formy budowli; 1978: T. Ośluk, Architektura bazylik wczesnochrześcijańskich w Syrii pótnocnej. Geneza, charakterystyka i rozwój; 1980: E. Wieruch, Ikonografia scen sarkofagowych ze św. Piotrem w IV wieku; 1981: R. Potręć, Malowidła mauzoleum Exodu w El-Bagawat na tle malarstwa wczesnochrześcijańskiego; P. Rosiński, Motyw krzyza w antyku chrześcijańskim. Geneza i najwcześniejsze formy; G. Haczewska, Związki układów przestrzennych centralnych budowli wczesnochrześcijańskich z koncepcjami antycznymi. Rozplanowanie; 1987: L. Nierychlewska, Ikonografia Najświętszej Maryi Panny w sztuce wczesnochrześcijańskiej (Maria - Ewa, Maria - Ecclesia, Maria - Theotokos).

${ }^{8}$ W r. 1984 Bożena Iwaszkiewicz-Wronikowska obroniła pracę $O$ motywach ikonograficznych malowidet przedkonstantyńskich w chrześcijańskich katakumbach Rzymu; w $1987 \mathrm{r}$. Ryszarda Potręć-Bulas pracę na temat sceny Przejścia przez Morze Czerwone w ikonografii późnego antyku, a w 1991 r. Daniel Próchniak - na temat Wczesnochrześcijańskich kościołów bezkoputowych w Armenii.

${ }^{9}$ Por. AU KUL, Akta osobowe Elżbiety Jastrzębowskiej, A 1142.

${ }^{10}$ Por. Ecclesia Mater - idea $i$ wyobrażenie na mozaice wczesnochrześcijańskiej z $V w$. z Tabarki, „Meander” 29(1974), s. 83-90.

11 Opublikowana jako Frise de l'abside de la première cathedrale de Faras, „Orientalia Christiana Periodica" 40(1974) 377-406. 
Od roku 1979 pracownikiem Katedry jest Daniel Próchniak (adiunkt od 1993 r.), którego naukowe zainteresowania koncentrują się na problematyce architektury wczesnochrześcijańskiej Armenii, rozpatrywanej w szerokim kontekście sztuki Bliskiego Wschodu. Dr Ryszarda Bulas, zatrudniona jako adiunkt w roku 1990, zajmuje się badaniem przede wszystkim zagadnień z dziedziny ikonologii i hermeneutyki obrazu, co znalazło wyraz m.in. w jej publikacji pt. Przejście przez Morze Czerwone - opowieść o lęku, przemianie i spetnieniu. Hermeneutyka obrazu (Lublin 2000) oraz sztuki Irlandii, której poświęcone są artykuły zebrane w tomie pt. Irlandia - między epokq kamienia a średniowieczem (Lublin 2000).

Zwieńczeniem starań Profesor Barbary Filarskiej o zakotwiczenie problematyki wczesnego chrześcijaństwa w dydaktyce uniwersyteckiej było wprowadzenie w roku akademickim 1991/92 do programu studiów historii sztuki kończącego się egzaminem wykładu z historii sztuki wczesnochrześcijańskiej. Tematem wykładu są początki sztuki chrześcijańskiej, jej geneza i najważniejsze zabytki (malarstwo katakumbowe, sarkofagi z III i IV wieku, pierwsze kościoły, fundacje Konstantyna Wielkiego, najstarsze mozaiki), zaś jego celem prześledzenie procesu powstawania, w okresie od III do VI wieku, ikonografii i architektury chrześcijańskiej.

Przejmując, jako następczyni Pani Profesor Filarskiej, kierowanie Katedrą Historii Sztuki Starożytnej, nie miałam wątpliwości, że do Jej najważniejszych osiągnięć należy stworzenie jedynej w Polsce uniwersyteckiej placówki prowadzącej badania i działalność dydaktyczną w zakresie sztuki wczesnochrześcijańskiej. Odchodząc z dniem 1 X 1992 r. na emeryturę, Pani Profesor Filarska pozostawiła dobrze wyposażoną w narzędzia pracy, w postaci dobrze zaopatrzonej biblioteki i tysięcy przeźroczy, Katedrę z trójką adiunktów, których zadaniem było przede wszystkim przekazywanie wiedzy o antyku, zwłaszcza antyku chrześcijańskim, na wykładach kursowych, na proseminariach i seminarium, a także na trzech wykładach monograficznych poświęconych ważnym w okresie późnego antyku i wczesnego średniowiecza obszarom - Irlandii ${ }^{12}$, północnej Italii ${ }^{13}$ i Armenii $^{14}$.

12 Tematem wykładu dr Ryszardy Bulas jest sztuka Wysp Brytyjskich w okresie I tysiąclecia n.e., w kontekście historii Kościoła celtyckiego, a zwłaszcza monastycyzmu. W oparciu o charakterystykę duchowości celtyckiej podejmuje interpretację symboli i motywów ikonograficznych. Zamierzeniem autorki jest pokazanie przejścia od pogańskiego do chrześcijańskiego celtyzmu.

${ }^{13} \mathrm{Dr}$ hab. Bożena Iwaszkiewicz-Wronikowska przedstawia topografię północno italskich prowincji w okresie wczesnego chrześcijaństwa, zmierzając do uchwycenia cech charakteryzujących proces chrystianizacji tego obszaru.

${ }^{14}$ Tematem wykładu dr. Daniela Próchniaka jest architektura i sztuka chrześcijańskiego Wschodu w okresie do VII wieku. Bliższa analiza tej problematyki ma na celu poszerzenie zakresu zajęć kursowych obejmujących historię sztuki starożytnej, wczesnochrześcijańskiej i średniowiecznej. 
Inną formą pracy naszej Katedry jest organizowanie sympozjów poświęconych kulturze świata późnego antyku i wczesnego chrześcijaństwa ${ }^{15}$. Staramy się w ten sposób nawiązywać do spotkań badaczy świata wczesnochrześcijańskiego, które odbywały się przed laty z inicjatywy Pani Prof. Filarskiej i Pani Prof. Małunowiczówny. Włączenie w program pracy Katedry problematyki archeologii chrześcijańskiej i sztuki okresu wczesnego chrześcijaństwa znalazło wyraz we wprowadzonej w 1995 r. zmianie jej nazwy na: Katedra Historii Sztuki Starożytnej i Wczesnochrześcijańskiej.

\section{L'ARCHEOLOGIA CRISTIANA NELL' UNIVERSITÀ CATTOLICA DI LUBLINO}

(Sommario)

Nell' Università Cattolica di Lublino l'archeologia cristiana esiste come disciplina storica dagli anni 70 grazie all'opera della professoressa Barbara Filarska, che in collaborazione con Centro degli Studi sull' Antichità Cristiana, per prima ha iniziato ad effettuare ricerche sull' arte paleocristiana includendo al contempo questa disciplina nel programma delle sue lezioni.

Il suo operare ha portato al raggiungimento di numerosi risultati tra i quali si evidenzia la pubblicazione di manuali concernenti la sudetta disciplina (i primi sul mercato polacco), il risveglio dell'interesse per l'archeologia cristiana tra gli studenti e la formazione di un gruppo di collaboratori, composto da ricercatori universitari (prof. B. Iwaszkiewicz-Wronikowska, dr R. Bulas, dr D. Próchniak), che tuttora sta continuando e ampliando le ricerche iniziate dalla professoressa svolgendo studi sull arte paleocristiana in Italia, in Irlanda e in Armenia.

${ }^{15}$ Materiały z dwóch pierwszych (1995 r.: Domus - ecclesia - aedes, powstawanie świątyni chrześcijańskiej; 1996 r.: Topografia świata wczesnochrześcijańskiego jako problem badawczy) ukazały się jako Sympozja Kazimierskie poświęcone kulturze świata późnego antyku i wczesnego chrześcijaństwa, red. B. Iwaszkiewicz-Wronikowska, Lublin 1998, z dwóch kolejnych (1998 r.: Topografia świata wczesnochrześcijańskiego w pracach polskich badaczy; 2000 r.: Miasto późnoantyczne - między starożytnościq a średniowieczem) są w druku. 